\title{
Prawo do czystego środowiska jako wartość konstytucyjna ${ }^{1}$
}

\author{
Wyrok irlandzkiego Sądu Najwyższego z dnia 31 lipca 2020 r., w sprawie \\ Friends of the Irish Environment v. The Government Ireland (Appeal No. 205/192)
}

Wyrok w irlandzkiej sprawie klimatycznej, unieważniający Plan klimatyczny, potwierdza, że na rządzących ciąży nie tylko obowiązek moralny i etyczny podjęcia zdecydowanych i konkretnych kroków mających na celu ochronę środowiska, lecz również obowiązek prawny. Jednakże stanowisko irlandzkiego Sądu Najwyższego, jakoby prawo do czystego środowiska nie znajdowało podstaw w zapisach Konstytucji jest nietrafione i nienależycie uargumentowane i stanowi swego rodzaju „krok wstecz" w świetle wcześniejszego orzecznictwa w tym zakresie.

\section{Joanna Marszałek}

Uniwersytet Gdański

j.marszalek@prawo.ug.edu.pl

ORCID: 0000-0002-5412-0935

https://doi.org/10.26881/gsp.2021.3.11

\section{Glosa}

W glosowanym judykacie irlandzki Sąd Najwyższy rozpoznał sprawę w składzie siedmiu sędziów ${ }^{3}$, w jakim orzeka się wyłącznie w sprawach dotyczących kwestii prawnych o szczególnym znaczeniu bądź wyjątkowo złożonych ${ }^{4}$. Nakazał rządowi Irlandii

\footnotetext{
1 W dokumentach międzynarodowych oraz w doktrynie stosuje się również pojęcia "prawo do zdrowego środowiska”, „prawo do bezpiecznego środowiska”, ,prawo do zadowalającego środowiska”, czy też w ujęciu ogólnym „prawo do środowiska”, zob. J. Rezmer, Prawo do informacji o środowisku z perspektywy organów powszechnego systemu ochrony praw człowieka oraz Europejskiego Trybunału Praw Człowieka [w:] Prawa człowieka a ochrona środowiska. Wspólne wartości i wyzwania, red. B. Gronowska, Toruń 2018, s. 304

2 https://www.courts.ie/acc/alfresco/681b8633-3f57-41b5-9362-8cbc8e7d9215/2020_IESC_49.pdf/ pdf\#view=fitH [dostęp: 12.04.2021].

3 Sąd Najwyższy w składzie: C.J. Clarke, P. Irvine, J. O’Donnell, J. MacMenamin, J. Dunne, J. O’Malley, J. Baker.

4 http://www.supremecourt.ie/supremecourt/sclibrary3.nsf/pagecurrent/36C4492DCD6C52E780257315005A419C?opendocument\&l=en [dostęp: 12.04.2021].
} 
podjęcie zdecydowanych kroków na rzecz osiągnięcia neutralności klimatycznej kra$\mathrm{ju}^{5}$, stwierdzając, że irlandzki Plan klimatyczny (National Mitigation Plan 2017-2022) ${ }^{6}$ jest zbyt ogólnikowy i jako taki niezgodny z obowiązującą ustawą o działaniach na rzecz klimatu i niskoemisyjnego rozwoju z 2015 r. (Ireland's Climate Action and Low Carbon Development Act). Autorka ocenia przedmiotowe orzeczenie pozytywnie, w szczególności biorąc pod uwagę materię, jakiej ono dotyczy, jednakże ma kilka krytycznych uwag odnośnie tej części judykatu, w której Sąd Najwyższy stwierdza, że prawo do czystego środowiska nie ma podstaw w Konstytucji. Biorąc pod uwagę okoliczność, że jest to drugi tego rodzaju wyrok na świecie ${ }^{7}$, warto ustosunkować się do poglądów wyrażonych w uzasadnieniu wyroku w „irlandzkiej sprawie klimatycznej”.

Bliższe rozważania na temat trafności rozstrzygnięcia trzeba jednakże rozpocząć od syntetycznego przedstawienia okoliczności sprawy. Fundacja Friends of the Irish Environment (FIE) wystąpiła do Wysokiego Trybunału ${ }^{8}$ z pozwem przeciwko dublińskiemu rządowi, podnosząc, że zatwierdzenie przez irlandzki rząd w 2017 r. krajowego Planu klimatycznego stanowiło naruszenie ustawy z 2015 r. (Ireland's Climate Action and Low Carbon Development Act), Konstytucji Irlandii oraz zobowiązań wynikających z Europejskiej Konwencji Praw Człowieka (EKPC), w szczególności prawa do życia oraz prawa do życia prywatnego i rodzinnego. Fundacja podniosła ponadto, że plan nie daje szans na osiągnięcie znacznych krótkoterminowych redukcji emisji. Wniosła tym samym o uchylenie decyzji rządu o zatwierdzeniu planu i w razie potrzeby napisanie nowego.

Wysoki Trybunał po rozpatrzeniu sprawy ${ }^{9}$ orzekł na korzyść rządu, stwierdzając, że rząd odpowiednio skorzystał ze swobody decyzyjnej przyznanej ustawą z 2015 r. ${ }^{10}$ W uzasadnieniu wskazano, że Plan, pomimo tego, że jest niezwykle ważny, stanowi wyłącznie „jeden element układanki". Wysoki Trybunał odrzucił tym samym argument podniesiony przez FIE, że rząd dopuścił się naruszenia Konstytucji i zobowiązań wynikających z EKPC.

\footnotetext{
5 Z uwagi na panującą pandemię Covid-19, uzasadnienie wyroku zostało ogłoszone on-line.

6 Dalej: Plan.

7 Pierwszy tego typu wyrok zapadł przed Holenderskim Sądem Najwyższym w Hadze w sprawie Fundacji Urgenda - The State of the Netherlands v. Urgenda Foundation (C/09/456689/ZA). W grudniu 2019 r. sąd zobowiązał rząd Królestwa Niderlandów do zrewidowania krajowej polityki klimatycznej. Sąd Najwyższy oddalił apelację, podkreślając, że holenderski rząd musi „działać biorąc pod uwagę fakt, że ryzyko groźnych zmian klimatycznych może mieć poważny wpływ na prawo do życia i dobrostanu mieszkańców Holandii". Jak podkreśliła prawnik fundacji, Thessa Khan „orzeczenie to stanowi precedens prawny istotny dla innych krajów o wysokiej emisji. Również one mogą być prawnie zobowiązane przez swoje sądy do podjęcia działań w sprawie zmian klimatu", zob. http://climatecasechart. com/non-us-case/urgenda-foundation-v-kingdom-of-the-netherlands/, https://300gospodarka. pl/300klimat/irlandia-sad-neutralnosc-klimatyczna-wyrok [dostęp: 13.04.2021].

8 System sądownictwa w Irlandii tworzą: Sąd Najwyższy (Supreme Court), Wysoki Trybunał (High Court), Sąd Apelacyjny (Court of Appeal) oraz sądy okręgowe (Circuit Court) i sądy rejonowe (District Court) I. Jankowska-Prochot, Właściwość irlandzkich Sądów Karnych, Prokuratura i Prawo 2018, nr 10, s.127

9 Wyrok Wysokiego Trybunału z dnia 19 września 2019 r. [2017 No. 793 JR].

10 Friends of the Environment CLG v. The Government of Ireland \& The Attorney General [2019] IEHC 747.
} 
Fundacja odwołała się od powyższego wyroku do Sądu Apelacyjnego, wnosząc jednocześnie wniosek o skierowanie sprawy bezpośrednio do Sądu Najwyższego. Sąd Najwyższy wyraził zgodę, stwierdzając, że wyjątkowe okoliczności sprawy, a ściślej konieczność pilnego podjęcia środków zaradczych w zakresie ochrony środowiska, uzasadniają odwołanie się bezpośrednio do Sądu Najwyższego.

Wyrokiem z dnia 31 lipca 2020 r. Sąd Najwyższy uchylił Plan klimatyczny, uznając, że nie spełnia on wymogów określonych w ustawie z 2015 r. z uwagi na to, że nie jest on wystarczająco szczegółowy. Jak wskazał, rozsądny i zainteresowany czytelnik Planu nie byłby w stanie zrozumieć, w jaki sposób Irlandia ma osiągnąć swoje cele redukcji emisji gazów cieplarnianych wyznaczone na rok 2050. Sąd Najwyższy stwierdził jednakże, że FIE nie posiada legitymacji do wnoszenia roszczeń na podstawie Konstytucji lub EKPC. Ponadto, w ocenie Sądu, FIE nie przedstawiło wystarczająco przekonującego argumentu, aby zidentyfikować niewymienione w Konstytucji Irlandii prawo do zdrowego środowiska, odrębne od praw wyraźnie przez nią przyznanych ${ }^{11}$.

Wyrok ten, będący precedensem, niewątpliwie stanowić może swego rodzaju przestrogę dla innych państw o wysokiej emisji gazów cieplarnianych, że jeśli nie zmienią swojej polityki w przedmiocie ochrony środowiska, mogą zostać zobowiązane przez sądy do podjęcia odpowiednich kroków w tym zakresie. Fundacja podniosła argumenty, jakoby Plan klimatyczny był zarówno niezgodny z prawem (naruszał ustawę z 2015 r.), jak i naruszał prawa człowieka wynikające z Konstytucji Irlandii oraz EKPC. Część wyroku stwierdzająca, że Plan jest niezgodny z prawem i musi zostać stworzony na nowo zasługuje na pełną aprobatę i uznanie, ponieważ wskazuje rządzącym, że od tego momentu ciąży na nich nie tylko obowiązek moralny i etyczny podjęcia zdecydowanych kroków mających na celu ochronę środowiska, lecz również obowiązek prawny. Należy zauważyć, że zapewnienie odpowiednich środków zmierzających do zagwarantowania skutecznej ochrony przysługujących jednostce praw, w tym prawa do czystego środowiska, jest konstytucyjną powinnością rządzących ${ }^{12}$. Państwo dostało sygnał, że musi działać szybciej i bardziej precyzyjnie, aby zmniejszyć zanieczyszczenie, które wpływa na zmianę klimatu kraju, co może mieć skutki nie tylko dla Irlandii, lecz także dla innych państw, które również mogą zostać zobowiązane przez sądy do wyznaczenia ambitnych i sensownych działań w tym zakresie. Należy mieć na uwadze, że regulacje odnoszące się do ochrony środowiska mają w przeważającej mierze publicznoprawny charakter, co jest konsekwencją uznania ochrony środowiska w kategoriach konstytucyjnego obowiązku władz publicznych ${ }^{13}$.

Autorka stwierdza jednak, że uzasadnienie wyroku w zakresie, w którym FIE odniosło porażkę, a mianowicie odnośnie argumentacji opartej na ochronie praw człowieka - jest lakoniczne, nietrafne i nie przekonuje swoją argumentacją.

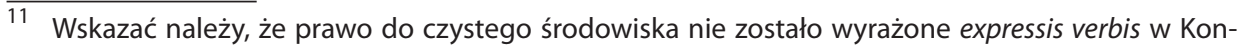
wencji o ochronie praw człowieka i podstawowych wolności, zob. J. Rezmer, Prawo do informacji o środowisku z perspektywy organów..., s. 303-304.

12 J. Trzewik, Publiczne prawa podmiotowe jednostki w systemie prawa ochrony środowiska, Lublin 2016, s.100.

13 Ibidem, s. 29.
} 
Wskazać bowiem należy, że prawo do czystego środowiska ${ }^{14}$ jest jednym z praw kolektywnych (solidarnościowych) ${ }^{15}$, należących do trzeciej generacji praw człowieka ${ }^{16}$. Prawa te nie mogą być urzeczywistniane bez połączenia wspólnego wysiłku wszystkich uczestników życia zbiorowego - zarówno jednostek, jak i państw, a także osób prywatnych i publicznych ${ }^{17}$. Życie w czystym środowisku jest takim samym przejawem przyrodzonej ludzkiej godności, jak inne prawa człowieka ${ }^{18}$. Nie ulega wątpliwości, że zdrowe i czyste środowisko jest niezbędnym warunkiem do korzystania z innych praw człowieka ${ }^{19}$. Europejski Trybunał Praw Człowieka na przestrzeni lat wydał wiele interesujących orzeczeń ${ }^{20}$, w których wskazał, że zanieczyszczenie środowiska może dotykać bezpośrednio jednostkę, co w konsekwencji może powodować naruszenie art. 8 EKPC traktującego o prawie do życia prywatnego i rodzinnego ${ }^{21}$.

$\mathrm{Na}$ tej podstawie FIE zdawała się postrzegać prawo do czystego środowiska jako wynikające z irlandzkiej Konstytucji, a dokładniej - z prawa do życia i prawa do nietykalności cielesnej. Sąd Najwyższy orzekł jednakże odmiennie, wskazując, że przedmiotowe prawo nie ma podstaw w irlandzkiej Konstytucji, w szczególności z uwagi na to, że jest zbyt niejasne i źle zdefiniowane ${ }^{22}$. Stanowisko takie, biorąc pod uwagę fakt, że ponad 150 krajów uznało prawo do środowiska na poziomie konstytucyjnym, a grupa organizacji pozarządowych wezwała ONZ do włączenia prawa do czystego środowiska do Powszechnej Deklaracji Praw Człowieka ${ }^{23}$, należało zatem ocenić krytycznie ${ }^{24}$.

\footnotetext{
14 W niektórych traktatach dotyczących praw człowieka, takich jak: Afrykańska Karta Praw Człowieka i Ludów, Protokół San Salvador do Amerykańskiej Konwencji Praw Człowieka czy też Konwencja o Prawach Dziecka, prawo do czystego środowiska zostało wyrażone expressis verbis, zob. J. Kapelańska-Pręgowska, P. Sadowski, Środowisko naturalne w sytuacji konfliktu zbrojnego - perspektywa prawnomiędzynarodowa [w:] Prawa człowieka a ochrona środowiska. Wspólne wartości i wyzwania, red. B. Gronowska, Toruń 2018, s.149.

15 Twórcą tej teorii był K. Vasak, który zaproponował katalog praw człowieka obejmujący prawo do czystej wody i zdrowego powietrza, który został przekształcony w prawo do zdrowego i czystego środowiska, zob. P. Korzeniowski, Bezpieczeństwo ekologiczne jako instytucja prawna ochrony środowiska, Łódź 2012, s. 28.

16 F. Nawrot, Prawo do czystego środowiska a implementacja Dyrektywy 2008/98/WE w Polsce i we Włoszech [w:] Prawa człowieka a ochrona..., s. 270.

17 W.M. Hrynicki, Potrzeba wzmocnienia międzynarodowej ochrony praw człowieka trzeciej generacji, „Kultura Bezpieczeństwa. Nauka - Praktyka - Refleksje” 2018, nr 30, s. 134.

18 A. Bodnar, Prawo do czystego środowiska jako prawo człowieka, Raport Klimat a Prawa Człowieka, s. 39, (https://ungc.org.pl/wp-content/uploads/2019/12/Klimat_a_Prawa_Człowieka_www.pdf [dostęp: 15.04 .2021$]$.

19 A. Mancewicz, Ochrona środowiska naturalnego prawem człowieka? Prawo do czystego środowiska w świetle orzecznictwa Europejskiego Trybunału Praw Człowieka, „In Gremio” 2007, nr 9, s. 16.

20 https://www.echr.coe.int/Documents/FS_Environment_ENG.pdf [dostęp: 15.04.2021].

21 Zob. wyroki w sprawach Greenpeace E.V. and others v. Germany (application no. 18215/06), Grimkovskaya v. Ukraine (application no. 38182/03).

${ }_{22}$ Pkt 9.5 uzasadnienia glosowanego wyroku.

23 https://www.birdlife.org/worldwide/news/our-campaign-make-healthy-natural-environmenthuman-right [dostęp: 15.04.2021].

24 Raport ONZ Environmental Rule of Law z 2019 r. (https://www.unep.org/resources/assessment/ environmental-rule-law-first-global-report [dostęp: 15.04.2021].
} 
Prawa tego rodzaju są przecież niejasne ze swojej natury i podlegają ewolucji w świetle dominujących poglądów ${ }^{25}$.

Sąd Najwyższy przywołał sprawę Friends of the Irish Environment v. Fingal County Council [2017] IEHC 695, w której stwierdzono, że prawo do środowiska, które jest zgodne z godnością ludzką oraz dobrobytem obywateli, jest podstawowym warunkiem realizacji wszystkich praw człowieka i jako takie podlega ochronie na podstawie Konstytucji $^{26}$. W ocenie jednakże Sądu Najwyższego, stanowisko takie jest niejasne, gdyż prawo takie musi być rozszerzeniem prawa, które Konstytucja przewiduje ${ }^{27}$. W tekście lub strukturze Konstytucji musi bowiem istnieć pewien trzon, z którego można wywodzić dane prawo. Może to wynikać z wartości konstytucyjnej, takiej jak godność czy demokratyczny charakter państwa. Nie może to jednakże wynikać z tego, że sędziowie po prostu zidentyfikowali prawa, które ich zdaniem winny być zawarte w Konsytucji ${ }^{28}$. Wobec takiej argumentacji, odrzucono tezę wskazaną w ww. wyroku, a także w argumentacji powoda. Takie stanowisko zdaje się „krokiem wstecz" w historii orzecznictwa związanego z ochroną środowiska. Sąd Najwyższy nie podał żadnych istotnych ani przekonywających argumentów, dlaczego wnioski płynące ze sprawy Friends of the Irish Environment v. Fingal County Council [2017] IEHC 695 nie mogą mieć przełożenia na przedmiotowy stan faktyczny.

Należy mieć również na uwadze, że we wskazanej już wcześniej sprawie Urgenda, sąd Niderlandów również podkreślił potencjalnie silne powiązania pomiędzy prawami człowieka a zobowiązaniami kraju w zakresie przeciwdziałania zmianom klimatycznym, czego w ocenie autorki zabrakło w glosowanym wyroku. Co prawda Sąd Najwyższy, kończąc swoje rozważania, wskazał, że będzie to prawdopodobnie kluczowa kwestia przyszłych sporów dotyczących środowiska i zostawił de facto otwartą furtkę przyszłym składom orzeczniczym, jednakże zdaje się to niewystarczające i zbyt zapobiegawcze.

Autorka wskazuje, że również w Polsce problematyka związana z ochroną klimatu i prawem do czystego środowiska jest równie istotna i przedmiotowe orzeczenie może wpłynąć także na stanowisko polskich sądów. Świadczy o tym zwrócenie się przez Sąd Okręgowy w Gliwicach z prośbą o rozstrzygnięcie przez Sąd Najwyższy zagadnienia prawnego budzącego poważne wątpliwości. Przed wspomnianym sądem toczy się bowiem postępowanie drugoinstancyjne w sprawie wytoczonej przez mieszkańca Rybnika przeciwko Skarbowi Państwa o ochronę dóbr osobistych. W ocenie powoda, zamieszkiwanie na terenie, na którym przekraczane są normy jakości powietrza powoduje dyskomfort psychiczny, a także poważne obawy związane z wpływem zanieczyszczonego powietrza na zdrowie, w tym ryzyko zachorowania na raka płuc czy astmę. W odpowiedzi na pozew pozwany podniósł, że powód nie udowodnił

\footnotetext{
25 https://www.ejiltalk.org/the-supreme-court-of-irelands-decision-in-friends-of-the-irishenvironment-v-government-of-ireland-climate-case-ireland/ [dostęp: 15.04.2021].

26 https://www.courts.ie/acc/alfresco/2156ec2e-9c44-409d-9e58-bb52e4349a25/2017_ IEHC_695_1.pdf/pdf\#view=fitH [dostęp: 17.04.2021].

27 Pkt 8.11 uzasadneinia glosowanego wyroku.

28 Pkt 8.6 uzasadnienia glosowanego wyroku.
} 
przesłanki istnienia dobra osobistego w postaci prawa do życia w czystym środowisku. Sąd pierwszej instancji oddalił powództwo z uwagi na to, że w jego ocenie powód nie wykazał, że doznał uszkodzenia ciała bądź rozstroju zdrowia na skutek smogu ${ }^{29}$. Sąd Okręgowy w Gliwicach powziął jednakże wątpliwości, co do argumentacji sądu rejonowego. Wobec tego, postanowił zwrócić się do Sądu Najwyższego z zapytaniem, „Czy prawo do życia w czystym środowisku umożliwiającym oddychanie powietrzem atmosferycznym spełniającym standardy jakości określone w przepisach powszechnie obowiązującego prawa, w miejscach, w których osoba przebywa przez dłuższy czas, w szczególności w miejscu zamieszkania, stanowi dobro osobiste podlegające ochronie na podstawie art. 23 k.c. w zw. $z$ art. 24 k.c. i art. 448 k.c.?"30

Sąd Najwyższy, uznając istnienie prawa jednostki do środowiska, miał możliwość nie tylko przyczynienia się do poprawy sytuacji prawnej osoby, której dobra osobiste zostały naruszone, lecz przede wszystkim mógł wpłynąć na jej faktyczną sytuację, doprowadzając do poprawy stanu środowiska, w którym ta osoba żyje ${ }^{31}$. Sąd Najwyższy wydał orzeczenie na rozprawie w dniu 28 maja 2021 r. i orzekł, że prawo do życia w środowisku umożliwiającym oddychanie czystym powietrzem nie stanowi dobra osobistego podlegającego ochronie. Dobrem osobistym, w jego ocenie, jest jednakże zdrowie, które może zostać naruszone właśnie na skutek oddychania zanieczyszczonym powietrzem. W ocenie autorki wyrażone przez Sąd Najwyższy stanowisko jest nieco rozczarowujące. Sąd Najwyższy wziął bowiem pod uwagę jedynie wąską definicję dóbr osobistych, a przecież katalog tychże dóbr ma charakter otwarty i istnieją dobra, które pomimo nieuwzględnienia ich w katalogu kodeksowym, mogą jako dobra osobiste podlegać ochronie cywilnoprawnej ${ }^{32}$. Z drugiej strony, co zasługuje na aprobatę, Sąd Najwyższy nie zamknął drogi do uzyskania cywilnoprawnej ochrony przed skutkami szkodliwego wpływu na środowisko, wskazując, że w takich sytuacjach możliwe będzie powołanie się na naruszenie takich dóbr osobistych jak zdrowie, czy życie ${ }^{33}$. Na ostateczną interpretację w tej sprawie będzie trzeba jednakże zaczekać do momentu wydania wyroku przez Sąd Okręgowy w Gliwicach, dla którego powyższa uchwała ma być jedynie wskazówką ${ }^{34}$.

Kolejną kwestią wymagającą rozważań jest legitymacja organizacji pozarządowej do wystąpienia z powództwem o naruszenie konstytucyjnych praw jednostki. Jak wskazał Sąd Najwyższy w omawianej sprawie, powód sam w sobie nie korzysta z prawa do życia czy też prawa do nietykalności cielesnej i jako taki nie posiada legitymacji

\footnotetext{
29 K. Doktór-Bindas, Prawo do czystego powietrza, Przegl. Konst. 2020, nr 4, s. 117-118.

$30 \mathrm{http}: / /$ www.sn.pl/sprawy/SitePages/e-Sprawa.aspx?ItemSID=2521-bf64e294-b9ca-4518-b9cd2b8c7295f4de\&ListName=esprawa2020\&Search=III\%20CZP\%2027/20 [dostęp: 19.04.2021].

31 J. Trzewik, Prawo do życia w czystym środowisku umożliwiającym oddychanie powietrzem atmosferycznym spełniajacym standardy jakości jako dobro osobiste - glosa do zagadnienia prawnego zarejestrowanego w Sądzie Najwyższym, III CZP 27/20, Przegl. Ustawodawstwa Gospodarczego 2021, nr 4, s. 58. 32 Ibidem.

33 https://www.rp.pl/Dobra-osobiste/306119912-Prawo-do-zycia-w-czystym-srodowisku-jako-dobr o-osobiste---uchwala-Sadu-Najwyzszego.html [dostęp: 22.07.2021].

34 https://www.teraz-srodowisko.pl/aktualnosci/oliwier-palarz-sad-najwyzszy-jakosc-powietrza-10388.html [dostęp: 22.07.2021].
} 
do wysunięcia argumentacji opartej na naruszeniu praw wynikających z Konstytucji lub EKPC ${ }^{35}$. Fundacja jest zatem „podmiotem prawnym, który wszczął niniejsze postępowanie, powołując się na prawa osobiste, z których w rzeczywistości nie korzysta" ${ }^{36}$.

Istotnie, FIE jest organizacją pozarządową, a nie osobą fizyczną, wobec czego nie może rościć sobie prawa do życia i nietykalności cielesnej. Nie ulega również wątpliwości, że możliwość przypisywania publicznych praw podmiotowych - których źródłem są przyrodzone prawa człowieka - osobom prawnym jest zagadnieniem niezwykle złożonym i problematycznym. Wynika to w szczególności z faktu, że przyrodzone prawa człowieka, takie jak życie czy zdrowie są tak silnie związane z istotą natury człowieka, że ich przenoszenie na twory sztuczne jawi się jako sprzeczne $z$ istotą tychże praw $^{37}$. Trudno jednakże zgodzić się w pełni z wyrażonym w tym zakresie przez Sąd Najwyższy stanowiskiem.

Należy mieć na uwadze, że wszelkie prawo bierze swój początek z przyrodzonych praw jednostki, jednak w literaturze wskazuje się, że możliwe jest przekazywanie przez nie części swojej podmiotowości również większym wspólnotom ${ }^{38}$. Zgodnie z irlandzkim porządkiem prawnym, legitymację do wniesienia skargi konstytucyjnej ma podmiot, którego prawa lub interesy zostały narażone lub istnieje wysokie zagrożenie ich naruszenia. Jednakże w sprawach wyjątkowych, w szczególności związanych z prawami konstytucyjnymi i prawami ustalonymi w EKPC, dopuszczalne jest bardziej „swobodne podejście” i rozciągnięcie legitymacji również na inne podmioty ${ }^{39}$. Sąd Najwyższy wskazał na tę możliwość, stwierdzając, że stałe zasady są elastyczne, ale „nie w nieskończoność" ${ }^{40}$. W przeciwieństwie do Sądu Najwyższego, rozpoznający sprawę w pierwszej instancji Wysoki Trybunał podszedł do tematu zdaje się rozsądniej, wskazując, że sprawa dotyczy istotnych kwestii związanych ze środowiskiem, mających znaczenie nie tylko dla członków organizacji, lecz także dla ogółu społeczeństwa, a tym samym powód posiada legitymację czynną do wystąpienia z powództwem ${ }^{41}$. Autorka ma na uwadze okoliczność, że komentowany wyrok może wyznaczyć kierunek, w którym będą podążały organizacje pozarządowe zajmujące się ochroną klimatu i przy następnej sprawie, z ostrożności procesowej, wystąpią jako powód wraz z osobą fizyczną, dzięki czemu nie narażą się na odrzucenie roszczenia z uwagi na brak legitymacji procesowej.

Komentowany wyrok ma niewątpliwie ogromne znaczenie dla wszelkich starań podjętych w celu ochrony środowiska. Może on bowiem stanowić z jednej strony trzon

35 Pkt 9.4 uzasadnienia glosowanego wyroku.

36 Pkt 7.22 uzasadnienia glosowanego wyroku.

37 E.K. Czech, Osoby fizyczne i osoby prawne jako podmioty publicznych praw podmiotowych, których źródłem sa przyrodzone prawa człowieka, „Krytyka Prawa” 2020, t. 12, nr 4, s. 233.

38 Ibidem, s. 230.

39 https://www.ejiltalk.org/the-supreme-court-of-irelands-decision-in-friends-of-the-irishenvironment-v-government-of-ireland-climate-case-ireland/ [dostęp: 15.04.2021].

40 Pkt 7.19 glosowanego wyroku.

41 Pkt 132 wyroku Wysokiego Trybunału [2017 No. 793 JR], http://blogs2.law.columbia.edu/climate-change-litigation/wp-content/uploads/sites/16/non-us-case-documents/2019/20190919_2017-No.-793-JR_judgment-2.pdf [dostęp: 15.04.2021]. 
przyszłych orzeczeń w krajach, których działania związane z ochroną środowiska zdają się zbyt powolne i nieskuteczne. Z drugiej strony, wątpliwości budzi kwestia odmowy uznania prawa do czystego środowiska za prawo mające podstawy w irlandzkiej Konstytucji, a także okoliczność odmówienia organizacjom pozarządowym legitymacji do walki o te prawa w imieniu jednostek. Należy jednak mieć na względzie fakt, że orzeczeniem tym nie zamknięto drogi przyszłym sprawom, w których podmioty będą się domagać ochrony swoich podstawowych praw związanych z czystym środowiskiem. Sąd zostawił bowiem otwartą furtkę osobom fizycznym, które stwierdzą, że działania państwa w zakresie ochrony środowiska mogą naruszać ich fundamentalne prawa i będą chciały dochodzić ich przez sądem.

Wobec tego, pomimo krytycznej oceny autora do wskazanej części wyroku, treść orzeczenia pozostawia nadzieję, że Sąd Najwyższy Irlandii jest w gotowości do zajęcia się w przyszłości problematyką naruszenia praw konstytucyjnych w interesujący i niespotykany dotychczas sposób, co niewątpliwie może mieć konsekwencje na podejście do problemu przez sądownictwo innych państw. Jak już wskazano, również w Polsce pojawił się problem związany z prawem człowieka do czystego środowiska, dlatego w ocenie autorki, komentowane orzeczenie jest tak istotne.

\section{Literatura}

Czech E.K., Osoby fizyczne i osoby prawne jako podmioty publicznych praw podmiotowych, których źródłem sa przyrodzone prawa człowieka, „Krytyka Prawa” 2020, t. 12, nr 4.

Doktór-Bindas K., Prawo do czystego powietrza, Przegl. Konst. 2020, nr 4.

Hrynicki W.M., Potrzeba wzmocnienia międzynarodowej ochrony praw człowieka trzeciej generacji, „Kultura Bezpieczeństwa. Nauka - Praktyka - Refleksje” 2018, nr 30.

Jankowska-Prochot I., Właściwość irlandzkich Sądów Karnych, „Prokuratura i Prawo” 2018, nr 10.

Kapelańska-Pręgowska J., Sadowski P., Środowisko naturalne w sytuacji konfliktu zbrojnego - perspektywa prawnomiędzynarodowa [w:] Prawa człowieka a ochrona środowiska. Wspólne wartości i wyzwania, red. B. Gronowska, Toruń 2018.

Korzeniowski P., Bezpieczeństwo ekologiczne jako instytucja prawna ochrony środowiska, Łódź 2012.

Mancewicz A., Ochrona środowiska naturalnego prawem człowieka? Prawo do czystego środowiska w świetle orzecznictwa Europejskiego Trybunału Praw Człowieka, „In gremio" 2007, nr 9.

Nawrot F., Prawo do czystego środowiska a implementacja Dyrektywy 2008/98/WE w Polsce i we Włoszech [w:] Prawa człowieka a ochrona środowiska. Wspólne wartości i wyzwania, red. B. Gronowska, Toruń 2018.

Rezmer J., Prawo do informacji o środowisku z perspektywy organów powszechnego systemu ochrony praw człowieka oraz Europejskiego Trybunału Praw Człowieka [w:] Prawa człowieka a ochrona środowiska. Wspólne wartości i wyzwania, red. B. Gronowska, Toruń 2018.

Trzewik J., Prawo do życia w czystym środowisku umożliwiającym oddychanie powietrzem atmosferycznym spełniającym standardy jakości jako dobro osobiste - glosa do zagadnienia prawnego zarejestrowanego w Sądzie Najwyższym, III CZP 27/20, Przegl. Ustawodawstwa Gospodarczego, $\mathrm{nr} 4 / 2021$. 
Trzewik J., Publiczne prawa podmiotowe jednostki w systemie prawa ochrony środowiska, Lublin 2016.

\section{Streszczenie}

Joanna Marszałek

Prawo do czystego środowiska jako wartość konstytucyjna

W niniejszej glosie Autorka przedstawiła wyrok w „irlandzkiej sprawie klimatycznej”, w której Sąd Najwyższy Irlandii unieważnił irlandzki Plan klimatyczny. Celem Autorki jest dokonanie analizy wyroku i odpowiedzenie na pytanie, czy Sąd Najwyższy prawidłowo odmówił zakwalifikowania prawa do zdrowego środowiska jako mającego źródło w irlandzkiej Konsytucji, a także, czy prawidłowo stwierdził, że organizacja Friends of the Irish Environment nie ma legitymacji czynnej do wytoczenia powództwa w tej sprawie.

Słowa kluczowe: klimat; ochrona środowiska; prawo do zdrowego środowiska.

\section{Summary}

\section{Joanna Marszałek}

\section{Right to a Healthy Environment as a Constitutional Value}

In the article, the Author presents the "Irish climate case" where the Supreme Court quashed the government's National Mitigation Plan. The Author aimed to analyse whether the Supreme Court was right to refuse to recognise the right to a healthy environment as a derived constitutional right and refuse Friends of the Irish Environment organization to litigate personal constitutional rights.

Key words: climate; environment protection; right to a healthy environment. 